\%、シリコンの 0.35〜0.45\% は 內部抵抗力には殆ど 關係が㷛い。次に實際の閭題 に就て一二の例を揭げる。第五圖は六本の腕を持つた車輸の一部であつてリムは鐥

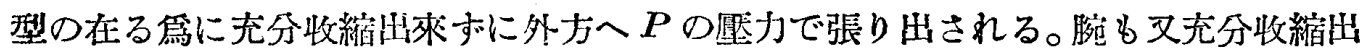
來然い爲に張力を受ける從つてリムに對しては $P_{1}$ と云ふ力を與へる。躊型は腕の 近所では他の部分より弱い故リムは幾分䛷の方に引寄せられ彎曲し第五圖の如くな る。彎曲モーメントを小くする䉆に腕の數を㑷すととも一つの方法であり又豫め木 型を㨊圓形として惪くのも其方法である。又湯口をリムと腕との境點に設け腕の冷 却するにつれてリムの引寄せらる১のを防ぐてとも宜しい。

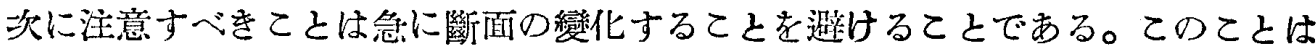

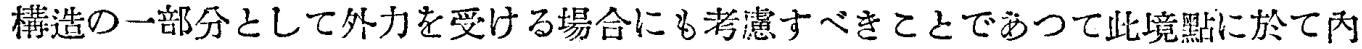

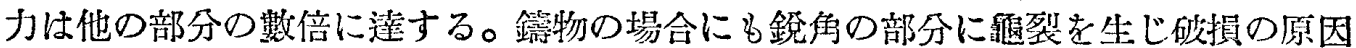

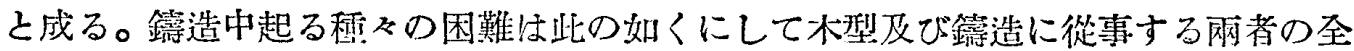
き了解に由つて除く事が出來るのである。

【26】燒戾脆性の原因飞關する物理的确究 [J. H. Andrew，\& H. A. Dickie in Glasgow ; Summer Meeting of I. \& S. I., 1926; Iron \& Coal Tr. Rev , Vol. 113, No. 3053, 1926-9-3, 頁 339-342, 圖 2, 表 5] 燒杘脆性の原因は今日に於

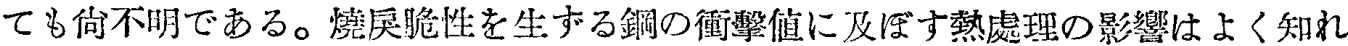
渡つた事賽であつて Greaves と Jones の詳紼なる政究結果が西る。又成分の變化 による影響に就ては同氏、Andrew \& Green 及 Grifithsによつて研究されて居る が十分なる說明は未だ發表されて居ない。衝慗值には變化があるが彈性照限及び磁 性の少量の變化を除いては他の機俄的並に物理的性質及び顯微鏡組織には殆ぞ變化 がない。この研究の第一部としては避當な試料を真空中で熱處理を施し比容㺓及び ブリネル硬度它测定しケ。

第一表の五種の鋼を比容積䳝料として 二組に分りた、（1） $850^{\circ} \mathrm{C}$ より注燒入の 後 $450^{\circ} \mathrm{C}$ 以上の各種溫度に 3 時指:燒㞔 しの後水冾、（2）同上處理なれど燒㞔し の後每分 $2^{\circ} \mathrm{C}$ の割合で徐冷。 $\mathrm{Ni}, \mathrm{Cr}$ を

\begin{tabular}{|c|c|c|c|c|c|c|c|}
\hline Steel. & $\begin{array}{c}\text { C. } \\
\text { Per } \\
\text { cent. }\end{array}$ & $\begin{array}{l}\text { Mn. } \\
\text { Per } \\
\text { cent. }\end{array}$ & $\begin{array}{c}\text { Si. } \\
\text { Per } \\
\text { cent. }\end{array}$ & $\begin{array}{c}\text { P. } \\
\text { Per } \\
\text { cent. }\end{array}$ & $\begin{array}{c}\text { S. } \\
\text { Per } \\
\text { cent. }\end{array}$ & $\begin{array}{l}\mathrm{Ni} . \\
\text { Per } \\
\text { cent. }\end{array}$ & $\begin{array}{l}\text { Cr. } \\
\text { Per } \\
\text { cent. }\end{array}$ \\
\hline A22 & 0.48 & 0.18 & 0.11 & - & - & - & - \\
\hline NPI & 0.31 & 0.75 & 0.112 & 0.013 & 0.029 & 3.64 & - \\
\hline NP5 & 0.33 & 0.70 & 0.065 & 0.098 & - & 3.66 & - \\
\hline AW22 & 0.33 & 0.52 & 0.17 & 0.016 & 0.014 & 3.48 & 0.76 \\
\hline$\triangle W 23$ & $0: 37$ & $0 . \tilde{24}$ & 0.149 & 0.013 & 0.012 & 4.55 & 1.14 \\
\hline
\end{tabular}
最多く含む銅 $\mathrm{AW} 23$ は $550^{\circ} \mathrm{C}$ 以上に於て比容蹟及び硬度に著しき變化を示したが。 
其の他の鋼は燒戻後急冾せるるのと徐冷せるものとの間に考を見出し得なかつた。 但し AW22 は比容債のみに稍美異を生じた。著しく燒㞔脆性を有する NP5 は殆 ぞ其の差異を生じなかつた。又一包の燒杘の後更に同一溫度で 3 時閆燒㞔してその ために何等かの差異を生ずるや否やを檢 べを(第二埊)。又 $\mathrm{AW} 23$ は $670^{\circ} \mathrm{C}$ で同 樣の試驗を施した。之れによると $670^{\circ} \mathrm{C}$ に於て 3 時間餘分に燒杘してb硬度に於 て 8 比签積に於て 0.000022 だけしか減 らなかつた。

次に第二部の研究として第三表の如を 五種の銅に就て二次の燒㞔の影響を檢べ

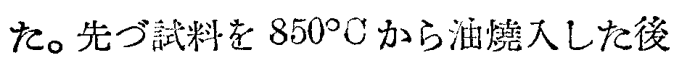
$650^{\circ} \mathrm{C}$ に 3 時間燒戾し水冷後更に $650^{\circ} \mathrm{C}$ に於て 6 時間燒杘の後水冷するてとを連 櫝的に行つた。その結果硬度に於て約 20、比容皘に於て 0.00004 の差を生じた。

TIBLE II,

\begin{tabular}{|c|c|c|c|c|c|}
\hline \multirow[t]{2}{*}{ Steel. } & \multicolumn{3}{|c|}{$\begin{array}{c}\text { Original treatment. } \\
\text { Tempered three hours at } \\
450 \text { deg. } C\end{array}$} & \multicolumn{2}{|c|}{$\begin{array}{l}\text { Repent at end"st } \\
\text { experiments. } \\
\text { Tempered three } \\
\text { hours at } 450 \text { deg. } \\
\text { C. (all quenched) }\end{array}$} \\
\hline & & $\begin{array}{l}\text { Specific } \\
\text { vol. }\end{array}$ & $\mid \begin{array}{c}\text { Brineli } \\
\text { hard- } \\
\text { ness. }\end{array}$ & $\begin{array}{l}\text { Specific } \\
\text { vol. }\end{array}$ & $\begin{array}{l}\text { Brineil } \\
\text { hard. } \\
\text { ness. }\end{array}$ \\
\hline \multirow[t]{2}{*}{ A22 } & Quenched & 0.127401 & 258 & 0.127381 & 258 \\
\hline & Slowly cooled & 0.127374 & $25 t$ & $0.127+18$ & 256 \\
\hline \multirow[t]{2}{*}{ NP1 } & Quenched & 0.127407 & 298 & 0.127397 & 289 \\
\hline & Slowly cooled & 0.127387 & 299 & 0.127416 & 287 \\
\hline \multirow[t]{2}{*}{ NP5 } & Quenched & 0.127430 & 302 & 0.127448 & 300 \\
\hline & Slowly cooled & 0.127407 & 300 & 0.127432 & 298 \\
\hline \multirow[t]{2}{*}{$\mathrm{AW} 22$} & Quenched & 0.127548 & $36 \tilde{5}$ & $0.12755 \mathrm{~L}$ & 356 \\
\hline & Slowly cooled & 0.127543 & 364 & 0.127552 & 361 \\
\hline \multirow[t]{2}{*}{ AW23 } & Quenched & 0.127666 & 369 & 0.127678 & 365 \\
\hline & Slowly cooled & 0.127677 & 367 & 0.127678 & 367 \\
\hline \multirow[t]{2}{*}{ Steel. } & \multicolumn{3}{|c|}{$\begin{array}{l}\text { Original treatment. } \\
\text { Tempered three hours at } \\
670 \text { deg. C. }\end{array}$} & \multicolumn{2}{|c|}{$\begin{array}{l}\text { Repeat treat. } \\
\text { ment. } \\
\text { Tempered six } \\
\text { hours at } 670 \text { decs. } \\
\therefore \text { (quenched). }\end{array}$} \\
\hline & & $\begin{array}{l}\text { Specitic } \\
\text { rol. }\end{array}$ & $\begin{array}{l}\text { Brinell } \\
\text { hard- } \\
\text { ness. }\end{array}$ & $\begin{array}{c}\text { Specific } \\
\text { vol. }\end{array}$ & $\begin{array}{l}\text { Brinell } \\
\text { hard. } \\
\text { ness. }\end{array}$ \\
\hline AW23 & $\begin{array}{l}\text { Quenched } \\
\text { Slowly cooled }\end{array}$ & $\begin{array}{l}0.327602 \\
0.127388\end{array}$ & $\begin{array}{l}248 \\
209\end{array}$ & $\begin{array}{l}0.127580 \\
0.127615\end{array}$ & $\begin{array}{l}240 \\
240\end{array}$ \\
\hline
\end{tabular}

即 $650^{\circ} \mathrm{C}$ に於けるものは龹れ以下に於ける場合よりも燒杘過剩の影響が大きい。份

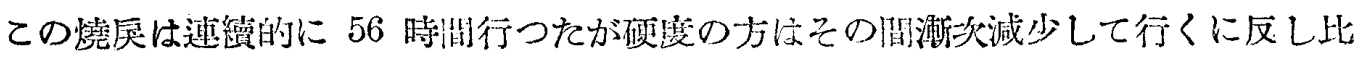

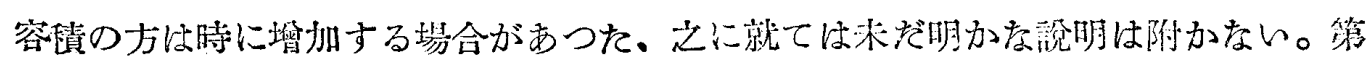
三部の研労には $\mathrm{AH}, \mathrm{NC}, \mathrm{NR} 3$ の鋼を 用みIzod 拭驗機を以て衝揧脆性を檢べ た。先づ $850^{\circ} \mathrm{C}$ から油燒入の後 650,670 , 680 及 $690^{\circ} \mathrm{C}$ に 2 時間烓杘した後一つ は水冷し他は最大脆性を得る樣に䜌分

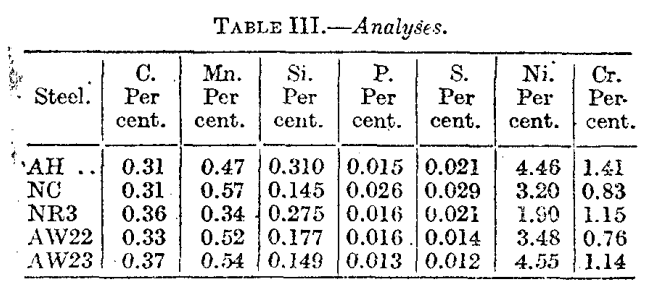

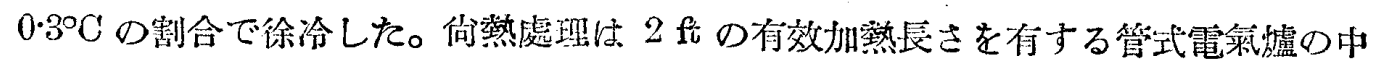

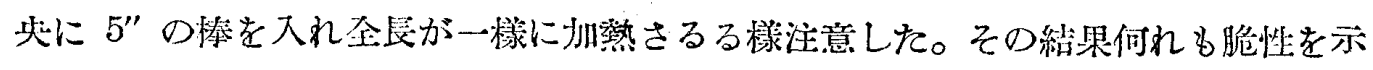

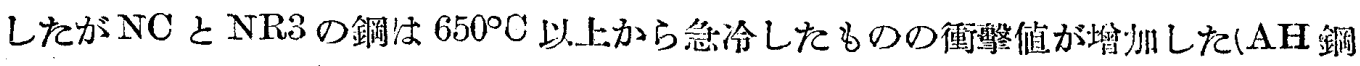

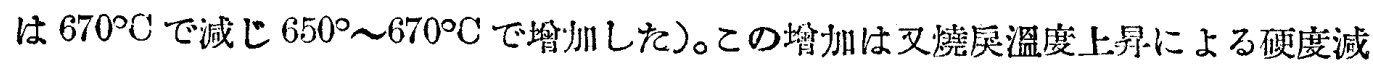
少を件つて居る。此賽驗によれば $\mathrm{Ac}_{1}$ 變態點を越さ奴範圍に於て燒杘溫度の高い程 
衝蒰值大をることを示す。然し $\mathrm{Ac}_{1}$ 索越せばマルテンサイトを生ずるから再び硬 度を增し衝㢣值を減ずる。第四部に於ては第一第三表の銅の他にクローム鋼 AXX (C 0.32 , Mn 0.91 , Si 0.145 , P 0.026, S 0.027, Cr 0.97\%) 高炭素ニツヶルクローム 銅 G2 (C 1·50, Mn 0.26, Ni 3*46, Cr 1·80\%) の二程の銅を用る物理的變化の最大 值を得るために最大脆性を得るを目的として處理した。鋼 $\mathrm{G} 2$ は $1,100^{\circ} \mathrm{C}$ から淇他 は $850^{\circ} \mathrm{C}$ から油燒入した。その結果は第匹表に示す。

TABLE IV.

\begin{tabular}{|c|c|c|c|c|c|c|c|c|c|c|}
\hline \multirow[t]{2}{*}{ Steel: } & \multicolumn{2}{|c|}{\begin{tabular}{c|} 
(1) \\
Oil-hardened and \\
tempered 650 deg. C. \\
for two hours and \\
water-quenched.
\end{tabular}} & \multicolumn{2}{|c|}{$\begin{array}{c}(2) \\
\text { Oil-hardened and } \\
\text { tempered } 650 \text { deg. } C . \\
\text { for two hours and } \\
\text { cooled at } 0.3 \text { deg. C. } \\
\text { per minute. }\end{array}$} & \multicolumn{2}{|c|}{$\begin{array}{c}(3) \\
\text { Oil-hardened and } \\
\text { tempered } 670 \text { deg. C. } \\
\text { for } 2 \frac{1}{2} \text {. hours and } \\
\text { cooled at } 0.3 \text { deg. C. } \\
\text { per minute. }\end{array}$} & \multicolumn{2}{|c|}{$\begin{array}{c}\text { (4) } \\
\text { Retempered } 550 \\
\text { deg. C. for three } \\
\text { hours and cooled at } \\
0.3 \text { deg. C. per } \\
\text { minute. }\end{array}$} & \multicolumn{2}{|c|}{$\begin{array}{c}(5) \\
\text { Oil-hardened and } \\
\text { tempered } 670 \mathrm{deg} . \mathrm{C} \text {. } \\
\text { for three hours and } \\
\text { cooled at } 2 \text { deg. C. } \\
\text { per minute. }\end{array}$} \\
\hline & Specific & Brinell & Specific & & Specific & & Specific & & Specific & \\
\hline$A H$ & 0.127694 & $\begin{array}{l}\text { ardness } \\
278\end{array}$ & 0.127698 & $\begin{array}{c}\text { ardness } \\
267\end{array}$ & 0.127693 & $\begin{array}{c}\text { Lardness } \\
266\end{array}$ & 0.127716 & $\begin{array}{l}\text { aness } \\
266\end{array}$ & 0.127577 & 252 \\
\hline & 0.127556 & 264 & 0.127617 & 242 & 0.127559 & 256 & 0.127565 & 254 & 0.127524 & 235 \\
\hline NR3 & 0.127611 & 266 & 0.127602 & 263 & 0.127630 & 269 & 0.127596 & 270 & 0.127543 & 245 \\
\hline AW22 & 0.127490 & 257 & 0.127466 & 247 & 0.127481 & 252 & 0.127487 & 249 & $\begin{array}{r}0.127337 \\
0.127492\end{array}$ & $\begin{array}{l}235 \\
238\end{array}$ \\
\hline AW23 & 0.127619 & 265 & 0.127592 & 230 & 0.127591 & 238 & 0.127613 & 235 & $\left\{\begin{array}{l}0.127482 \\
0.127490\end{array}\right.$ & $\begin{array}{l}238 \\
239\end{array}$ \\
\hline A 22 & 0.127364 & 177 & 0.127368 & 170 & 0.127361 & 168 & $0.12736 \mathrm{I}$ & 170. & $0.12735 \mathrm{I}$ & 165 \\
\hline $\mathrm{NPl}$ & 0.127330 & & 0.12 & 19 & & 19 & 0.127318 & & & 19 \\
\hline NPE & 0.127353 & 211 & 0.127288 & & 0.127264 & 19 & 0.127303 & & 0.127249 & 211 \\
\hline$A X X$ & 0.127625 & 261 & 0.127569 & 257 & $0.12763 i$ & 215 & 0.127650 & 215 & 0.127620 & 228 \\
\hline$\$ 2$ & - & - & 0.128120 & 401 & 0.128109 & 364 & 0.128063 & 331 & 0.128004 & 284 \\
\hline
\end{tabular}

この結果を見ると硬度並びに比容積の變化は中位の冾却秋度の場合に生和るこど 交知る。第五部の研究としては次の鋼に就て比签積及ひ硬度に及压す冾却速度の影

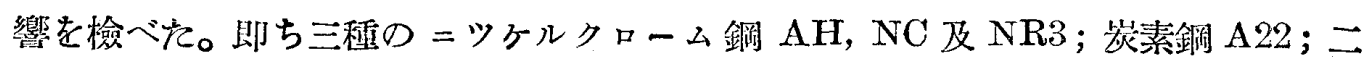

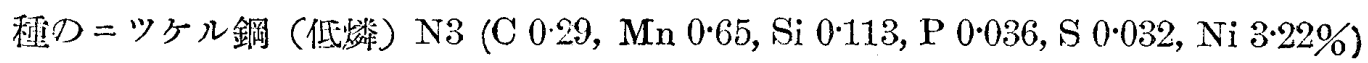
及 (高燐) NP5；クローム鋼 AXX の七程である。之等を $850^{\circ} \mathrm{C}$ から油燒入れの

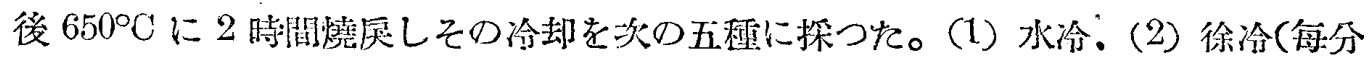

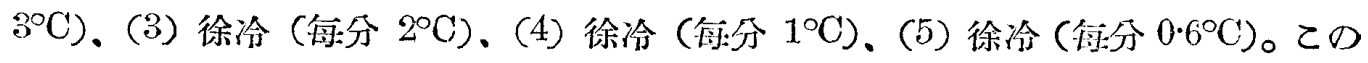
絬果ニツヶルクローム鋼の硬度及び比容積が中位の冷却速度で減少するてとが確め られた。今までての變化が見出されなかつたの慓集燒杘溫度 $650^{\circ} \mathrm{C}$ 以下で行つ

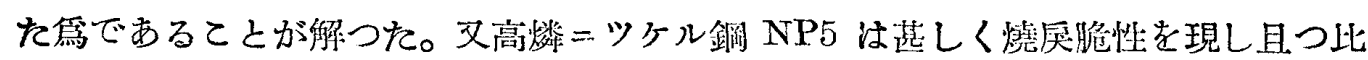
容漬谱に硬度に變化あるととを知つた。低燐ニツらル銅 N3 は硬度にのみ稍變化を

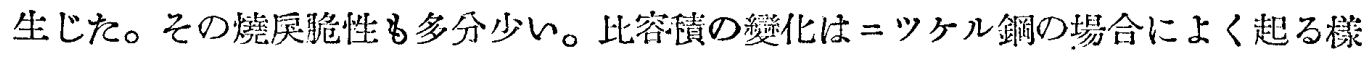
に燒戻過剩によつて全く被はれたのである。

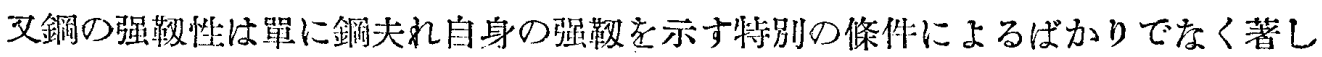


く徐冷せることによる脆性のなきてとに關係するものらしん。次に第六部の研究で は五種の ニツケルクローム鋼に就て强靶性に及压す燒杘溫度の影響を檢べた。即 $\mathrm{AH}, \mathrm{NC}, \mathrm{NR} 3, \mathrm{AW} 22$ 及 $\mathrm{AW} 23$ の試料を $850^{\circ} \mathrm{C}$ 加油燒入の後 $300^{\circ} \mathrm{C}$ で 6 時 間燒杘した後硬度及び比容嫧を测定し、 $400^{\circ} \mathrm{C}$ で更に燒杘を施し䐓次連續的に燒杘

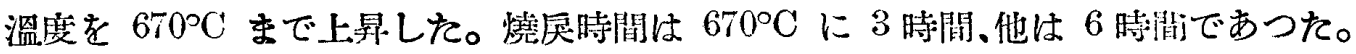

その結果を曲線にとつたが大なる變化を認めなかつた。此容漬は燒杘溫度上景と 共に脆性範圍に於てすら稍增加して曲線に折點を示したが硬度曲線は滑かに減少し た。又之等の曲線によりニツケルクローム錩に於ては燒㞔溫度高きときは燒杘過剩 の影響が莧だ少いてとを知る。第七部の研究は物理的性質の變化の說明を得るため に行はれた。前記實驗のらち=ツケル鋼 N3が之に解決を與へたもので、先づての鋼 を $695^{\circ} \mathrm{C}$ に於てセヌンタイトが笔全に溶け达む迄加熱し、一つは水冷他は $400^{\circ} \mathrm{C}$ 迄注分 $0.3^{\circ} \mathrm{C}$ 割合で徐冷した後引張り試驗及 I Zod 衝擊試驗を施した。之等試料 と共に監かれた顯微鏡試驗試料を見れば徐冷せるものはセメンタイトが結晶粒界に 沿ふて完全な膜として析出されて居る。然为之は燒鈍せるものよりも硬度が高い。 衝慗試驗の結果は他の實驗に見られない程變つて居た、又破壊試驗片の硬度を測定 すると兩端其の值を異にして居た(第一圖)。ての現像怡脆性範園に於ける特殊銅の 狀態と同樣なるのと洘へられる。

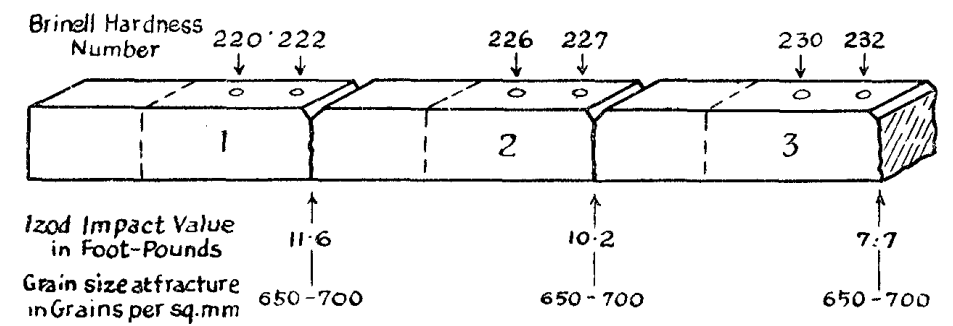

Fig. 1

（第一圖 Izod 試驗片の切缺けは混效を防ぐために一面にのみつけたが筫物は三面

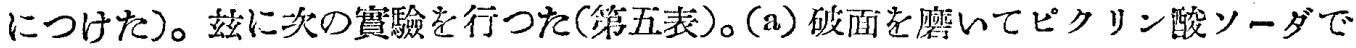
㐗沸しセメンタイトの配置を檢べた結果各部結晶粘の大さは異らないが、衝摮值低 く硬度大なる部分は粒界のもメンタイトが明かに餘計あつた。(b) 各破面の比容積

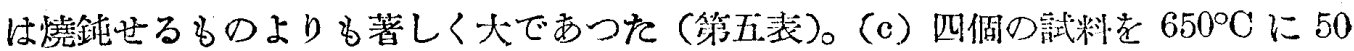

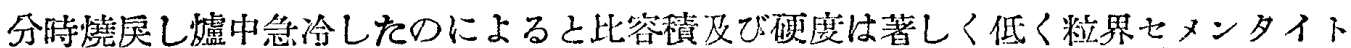


は粒状に分れて居た、即ち組織の變化に件つて性質の變化を來たしたてとを知る。

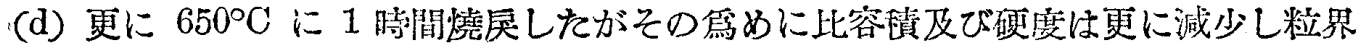

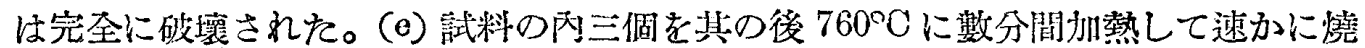
鈍した後爐中冷却した、其結果は比容輤及び硬度は（b）の場合よりる低かつた。

TABLE V.-Seventh Series of Experiments.

\begin{tabular}{|c|c|c|c|c|c|c|c|c|}
\hline Specimen. & \multicolumn{2}{|c|}{$\begin{array}{c}\text { Experiment ' }(b) \text {. } \\
\text { Grain boundary } \\
\text { condition. }\end{array}$} & \multicolumn{2}{|c|}{$\begin{array}{c}\text { Experiment }(c) . \\
\text { Tempered fifteen } \\
\text { minutes at } 650 \text { deg. } \mathrm{C} .\end{array}$} & \multicolumn{2}{|c|}{$\begin{array}{l}\text { Experiment }(d) \text {. } \\
\text { Retempered one hour } \\
\text { at } 650 \mathrm{deg} . \mathrm{C} \text {. }\end{array}$} & \multicolumn{2}{|c|}{$\begin{array}{c}\text { Experiment }(e) . \\
\text { Annealed at } 760 \text { deg. } C\end{array}$} \\
\hline $\begin{array}{l}1 \ldots \\
2 \ldots \\
3 \ldots 9 \\
4 \ldots\end{array}$ & $\begin{array}{c}\text { Specific } \\
\text { Yol. } \\
0.127427 \\
0.127479 \\
0.127456 \\
0.127458\end{array}$ & $\begin{array}{c}\text { Brinell } \\
\text { hardness. } \\
220 \\
226 \\
230 \\
243\end{array}$ & $\begin{array}{c}\text { Specific } \\
\text { Vol. } \\
0.127372 \\
0.127389 \\
0.127395 \\
0.127363\end{array}$ & $\begin{array}{c}\text { Brinell } \\
\text { hardness. } \\
177 \\
191 \\
194 \\
183\end{array}$ & $\begin{array}{c}\text { Specifio } \\
\text { Vol. } \\
0.127265 \\
0.127279 \\
0.127284 \\
0.127270\end{array}$ & $\begin{array}{c}\text { Brinell } \\
\text { hardness. } \\
166 \\
164 \\
168 \\
176\end{array}$ & $\begin{array}{c}\text { Specific } \\
\text { Vol. } \\
0.127375 \\
0.127356 \\
0.127395 \\
\text { (not treated) }\end{array}$ & $\begin{array}{c}\text { Brinell } \\
\text { hardness. } \\
198 \\
201 \\
203 \\
-\end{array}$ \\
\hline
\end{tabular}

セメンタイトが粒界にあるものは头れがフェライトと混合して細かく分们されて 居る者よりも硬んのは、前者はフエライトの變形を妨げること大であるが、後者は夫 れが少いからでする。セメンタイトが粘界にあるものは酎張力 56.4 tons $/ \mathrm{in}^{2}$ 、伸で

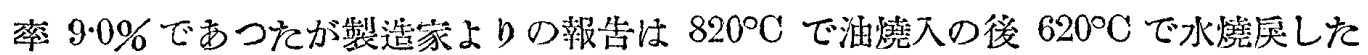
ものは 55 tons $/ \mathrm{in}^{2} 、 20$ 25\% であつた。之等の数字は嚴格な意味では比較すべき でないが大顝粒界セメンタイトあるものは耐張力には大なる影響をく伸びは約牛分

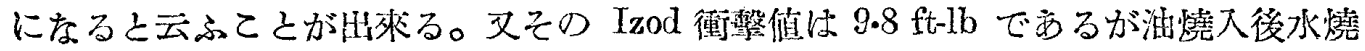

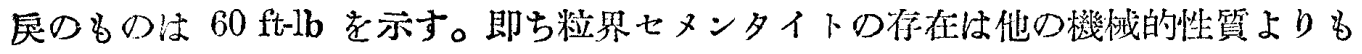
衝撃値に著しくその影響が現るるととを知る。

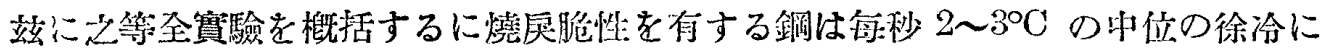
よつて比容積及び硬度にかるりの減少を見る。又この冷却速度に低つては衙整倠に は比教的少量の變化しか生じない。又乙の物理的性筫の變化量は極徐喻の場合に生 ボる脆性の程㦄に比例して居る。即ち脆性大なるニツヶルクローム銅では上記性質 の變化も大であるが、脆性少きニツケル鋼及びクローム鋼は上記性筫の變化も少い。

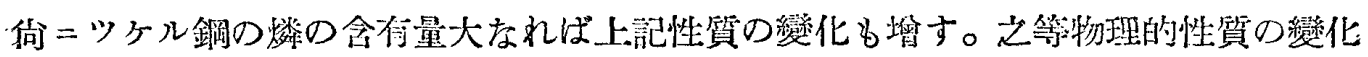
は燒危溫磨に於て鋼の固溶體中にあるセメンタイトとか鐵とクロームとの複炭化物 の如き溶質が分離するととに低る。 $\mathrm{Ni}, \mathrm{Mn}, \mathrm{Cr}, \mathrm{P}$ の如き元素は $\mathrm{Ac}_{1}$ 點に近き溫 度に於てセメンタイトをフェライト中に溶け达み易からしめ、且つ徐冾つ場合低溫 度で再び析出せしむる傾向が多い。又国溶體からセメンタイトの析出するてとのみ 
で脆性を說明するてとは出棵ない。その析出せるセヌンタイトの分布狀態によつて 脆性を說明し得るのである。

\section{3. 测定機およひ測定法}

【27】燒入金屬硬度测定法の比較結果 [N. Sawine, in Pétrograd, Le Génie Civil, Tome 89, No. 8, 1926-8-21, 頁 159-161, 圖 7, 表 2] 多くの硬度測定 法のらち一般用として門く用みられて居るのは Brinell の硬度計であるが、燒入金 屬の硬度測定には普通のBrinel]の球を使用しては滿足なる結果を得られないので、 近頃その目的の爲めには Hultgren の洘案せる極めて硬き SKF 球か或注四面角錐 又は圆錐形に磨かれたるダイヤモンドを使用して居る者るする。Fig. 1〜 Fig. 3 は：Vickers の硬度計を示す。即ち中介柄 A によつて槙桿 しの右端に掛けてある 重りを働かしむれば、試料にダイヤモンド D が壓入する仕脚けですつて試驗に 30 秒はかからない。試驗の初めに際しては槙桿 し はダツシュポツトKのエキセント． リツク $\mathrm{F}$ 上の唡 $\mathrm{P}$ によつて支へられる。次に重量 Wによりェキとントリック $\mathrm{F}$ は趈轉され梖棉 L は汥へを外されてダイヤモンド D 它押す。乙の間約 20 秒を要 した後 し は再び元の位蒀に杘される。かくて試驗片はダイヤモンドの釦錐の四面 によつて作られたる四角の跡形 (第三圖)を極印される。々の跡形の凹部は $136^{\circ} を$ なして居る(第二圖)。さて次に試片を 載せを臺 Sを下げ後機成の脇の部分に 取り付けれらを䋈微鏡を跡形の上に向 けてその對角線を測定する。之より附 屬表により之に相當する Brinell 硬度 数を見出すのである。米國に於ては Rockwell の裝置索㵱重して居る。最 近圓錐形のダイヤモンドを挿入しその 上に槓梠の中央にある重りを振動さす 樣に作られ、ダイヤモンドの動きによ り銳钽な指示器の針が沈みの深さを示 す樣になつて居る。試驗時閐はダッシュ

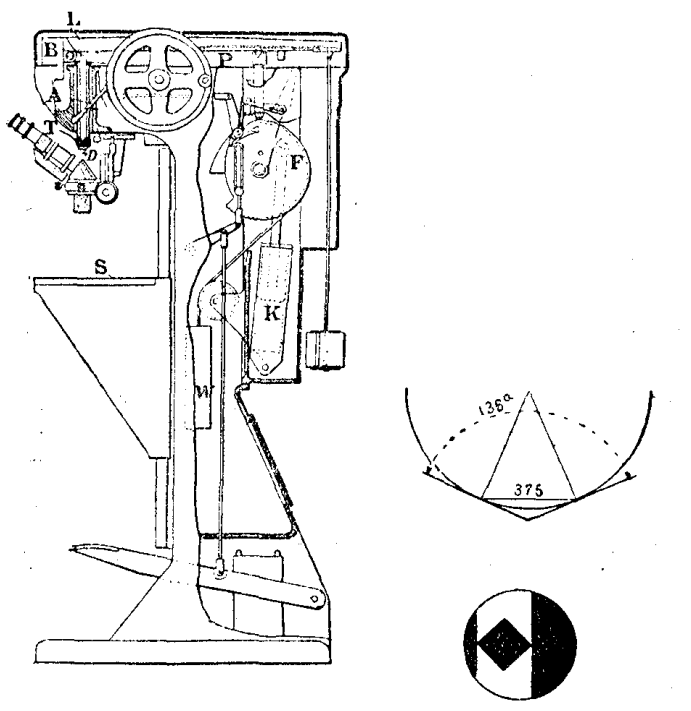

Fig. 1. 楚置の切断正面圖 Fig. 2. ダイヤモンドの尖端 Fig. 3. 䄚印の平面圖 Vickers 型硬度測定装置 